\title{
An Economic Study: Scenario of Cropping pattern and Cropping Intensity to Mustard cultivation of Meerut district of Western Uttar Pradesh, India
}

\author{
Prince Kumar $^{1 *}$ and David Chella Baskar ${ }^{2}$ \\ Rani Lakshmi Bai Central Agricultural University, Jhansi, Uttar Pradesh,-284003 (India) \\ *Corresponding author
}

\section{A B S T R A C T}

\begin{tabular}{|l|}
\hline Ke y w o r d s \\
$\begin{array}{l}\text { Cropping pattern, } \\
\text { Cropping intensity, } \\
\text { Total cultivated } \\
\text { area, Average } \\
\text { productivity }\end{array}$ \\
\hline Article Info \\
\hline $\begin{array}{l}\text { Accepted: } \\
\text { 21 May } 2020 \\
\text { Available Online: } \\
\text { 10 June } 2020\end{array}$ \\
\hline
\end{tabular}

Cropping pattern is a method to produced different types of crop in a particular area. Crop pattern are directly related to grow different crops. Cropping pattern of crops in agriculture is also practiced with a view to assess avoid risk due to climate condition and biological variability. Cropping pattern of crop provides better economic liability with grown value added agricultural products and also improvement of cropping intensity. Cropping pattern is very necessary measurement to analyze of the cropping intensity. This paper is an attempt to analyze the cropping pattern and cropping intensity of the study area. Cropping pattern is the efficient matter of agricultural production, which highly controlled the entire economic status of the study area. Because some villages were famous for multiple crop production. Different type of crop production in different areas of this block creates cropping intensity. India is the third largest rapeseed-mustard producer in the world, accounting for about $12 \%$ of the world's total rapeseed-mustard. Area, production and productivity of Rapeseed- mustard in India were 5.96 million hectares, 8.32 million tonnes, and $1397 \mathrm{~kg} / \mathrm{ha}$ respectively. (Directorate of Economics and statistics, New Delhi 2017-18)

\section{Introduction}

Mustard belongs to cruciferae family and genus Brassica. Mustard (Brassica junecea) is also known as Rabi or laha. According to various scientists, Mustard is originated from china and spread over India from there. India is one of the largest producers of mustard in the world. The production of mustard in India is around 16.2 million tones which account for about $18 \%$ of the total oil seed production of the country (Modern techniques of raising field crops by Chhidda Singh page 33, Second
Edition-2009). India is the third largest rapeseed-mustard producer in the world, accounting for about $12 \%$ of the world's total rapeseed-mustard "seed" and about $8.5 \%$ of the world's total rapeseed-mustard "oil".

In India, rapeseed-mustard is grown in diverse agro-climatic conditions ranging from north-eastern/north- western hills to down south. The crop is grown sole or in mixed cropping under both rainfed or irrigated conditions of the total area and production under the nine oilseeds crops grown in India, 
rapeseed-mustard accounts for $22.2 \%$ of the acreage and $22.6 \%$ of the production. The average rapeseed-mustard yield in India is about $1145 \mathrm{~kg} / \mathrm{ha}$ compared to the combined oilseeds crops average of $1135 \mathrm{~kg} / \mathrm{ha}$. In India, although, rapeseed-mustard is cultivated in 13 states, production in Rajasthan, Uttar Pradesh, Haryana and West Bengal, with their respective share of 45,13 , 11 and $8 \%$ accounts for $77 \%$ of the National total. In the last 15 years, introduction of high-yielding rapeseed-mustard varieties, hybrids, improved production technology, increased area under cultivation; government price support policies and institutional support have revealed positive trends. The study was carried out for estimating cropping pattern in Meerut district of western Uttar Pradesh and to analyse the cropping intensity.

\section{Materials and Methods}

Keeping in view the objective of the study, Meerut district of western Uttar Pradesh was purposively selected. Block wise data on the area under mustard and the total cropped area were obtaining from secondary sources. Based on data block wise percentage area under mustard to the corresponding total crop area of the block was calculating \& these blocks were arranged in descending order. The two blocks with maximum percentage area under mustard were selected. For each selected block, percentage area under mustard to the corresponding total cropped area was worked out for each of the villages of the block \& the ten villages, having maximum concentration of relative area under mustard were selected from each of the selected two block. The data pertained for the agriculture year 2012-2013.

For each selected randomly of village, a separate list of mustard growing farmers was prepared and these farmers was regarded in to marginal (below 1ha.), small (1-2 ha), medium (2-4 ha), and large (4 ha \& above) size group of farms. From each selected randomly of villages, 100 farmers were randomly selected. The allocation of these 100 selected farms of a selected randomly of villages in to marginal, small, medium, and large farms was based on the proportion of the mustard growing farms under each size groups to the total mustard growing farms.

\section{Results and Discussion}

Meerut district for agriculture is highly diversified. Paddy and wheat are most important cops in Meerut district. Cropping pattern presents the area devoted to the various crop during the given period, conventionally in a single year. It indicates the yearly sequence and arrangement of crops grown by farmer in a particular area. The cropping patterns followed by the sample farms are presented on an average the highest area was covered under paddy (13.25 per cent) followed by wheat (12.98 per cent), mustard (11.60 per cent), and jwar (9.68 per cent) of total cropped area on the sample farms. Paddy and wheat is the main crop raised by the sample farms after Mustard. The gross cultivated area was higher in the kharif season and less in the Zaid season on all farm situations. It is also clear from the table 1 that Mustard (8.29 per cent) in the Rabi season of total cropped area. Large farmers devoting highest area for cultivation of mustard (7.47 per cent) followed by marginal (12.32 per cent), small (10.67 per cent), and medium (8.29 per cent) respectively of their total cultivated area.

\section{Cropping intensity}

Cropping Intensity depends on a number of various factors-the land should be level and fertile, goods quality of seeds particularly HYV of seeds should be available, assured supply of water etc. (Table 2). 
Table.1 Cropping pattern under different size group of farms (area in ha)

\begin{tabular}{|c|c|c|c|c|c|c|}
\hline \multirow[t]{2}{*}{ S. No. } & \multirow[t]{2}{*}{ Crops } & \multicolumn{4}{|c|}{ Average size of sample farms } & \multirow{2}{*}{$\begin{array}{l}\text { Overall } \\
\text { average }\end{array}$} \\
\hline & & Marginal & Small & Medium & Large & \\
\hline $\mathbf{A}$ & Kharif & & & & & \\
\hline 1. & Jwar & $\begin{array}{c}0.15 \\
(10.27)\end{array}$ & $\begin{array}{c}0.35 \\
(10.67)\end{array}$ & $\begin{array}{c}0.47 \\
(7.35)\end{array}$ & $\begin{array}{c}0.62 \\
(6.91)\end{array}$ & $\begin{array}{c}0.35 \\
(9.68)\end{array}$ \\
\hline 2. & Paddy & $\begin{array}{c}0.20 \\
(13.69)\end{array}$ & $\begin{array}{c}0.40 \\
(12.19)\end{array}$ & $\begin{array}{c}0.91 \\
(14.24)\end{array}$ & $\begin{array}{c}1.08 \\
(12.05)\end{array}$ & $\begin{array}{c}0.48 \\
(13.25)\end{array}$ \\
\hline 3. & Maize & $\begin{array}{c}0.08 \\
(5.48)\end{array}$ & $\begin{array}{c}0.18 \\
(5.48)\end{array}$ & $\begin{array}{c}0.32 \\
(5.00)\end{array}$ & $\begin{array}{c}0.51 \\
(5.69)\end{array}$ & $\begin{array}{c}0.27 \\
(7.45)\end{array}$ \\
\hline 4. & Bajra & $\begin{array}{c}0.05 \\
(3.42)\end{array}$ & $\begin{array}{c}0.16 \\
(4.87)\end{array}$ & $\begin{array}{c}0.41 \\
(6.41)\end{array}$ & $\begin{array}{c}0.45 \\
(5.02)\end{array}$ & $\begin{array}{c}0.18 \\
(4.97)\end{array}$ \\
\hline \multirow[t]{2}{*}{5.} & Vegetable & $\begin{array}{c}0.06 \\
(4.10)\end{array}$ & $\begin{array}{c}0.15 \\
(4.57)\end{array}$ & $\begin{array}{c}0.35 \\
(5.47)\end{array}$ & $\begin{array}{c}0.73 \\
(8.14)\end{array}$ & $\begin{array}{c}0.17 \\
(4.69)\end{array}$ \\
\hline & Total & $\begin{array}{c}0.54 \\
(36.96) \\
\end{array}$ & $\begin{array}{c}1.24 \\
(37.78)\end{array}$ & $\begin{array}{c}2.46 \\
(38.47)\end{array}$ & $\begin{array}{c}3.39 \\
(\mathbf{3 7 . 8 1})\end{array}$ & $\begin{array}{c}1.45 \\
(40.05)\end{array}$ \\
\hline B & Rabi & & & & & \\
\hline 1. & Mustard & $\begin{array}{c}0.18 \\
(12.32)\end{array}$ & $\begin{array}{c}0.35 \\
(10.67)\end{array}$ & $\begin{array}{c}0.53 \\
(8.29)\end{array}$ & $\begin{array}{c}0.67 \\
(7.47)\end{array}$ & $\begin{array}{c}0.42 \\
(11.60)\end{array}$ \\
\hline 2. & Wheat & $\begin{array}{c}0.27 \\
(18.49)\end{array}$ & $\begin{array}{c}0.48 \\
(14.63)\end{array}$ & $\begin{array}{c}1.09 \\
(17.05)\end{array}$ & $\begin{array}{c}1.05 \\
(11.71)\end{array}$ & $\begin{array}{c}0.47 \\
(12.98)\end{array}$ \\
\hline 3. & Pea & $\begin{array}{c}0.01 \\
(0.68)\end{array}$ & $\begin{array}{c}0.12 \\
(3.65)\end{array}$ & $\begin{array}{c}0.32 \\
(5.00)\end{array}$ & $\begin{array}{c}0.41 \\
(4.57)\end{array}$ & $\begin{array}{c}0.16 \\
(4.41)\end{array}$ \\
\hline 4. & Potato & $\begin{array}{c}0.04 \\
(2.73)\end{array}$ & $\begin{array}{c}0.16 \\
(4.87)\end{array}$ & $\begin{array}{l}0.37 \\
5.79)\end{array}$ & $\begin{array}{c}0.70 \\
(7.81)\end{array}$ & $\begin{array}{c}0.19 \\
(5.24)\end{array}$ \\
\hline \multirow[t]{2}{*}{5.} & Berseem & $\begin{array}{c}0.04 \\
(2.73)\end{array}$ & $\begin{array}{c}0.09 \\
(2.74)\end{array}$ & $\begin{array}{l}0.19 \\
2.97\end{array}$ & $\begin{array}{c}0.46 \\
(5.13)\end{array}$ & $\begin{array}{c}0.13 \\
(3.59)\end{array}$ \\
\hline & Total & $\begin{array}{c}0.53 \\
(36.95)\end{array}$ & $\begin{array}{c}1.20 \\
(36.56)\end{array}$ & $\begin{array}{c}2.41 \\
(39.10)\end{array}$ & $\begin{array}{c}3.29 \\
(36.69)\end{array}$ & $\begin{array}{c}1.37 \\
(\mathbf{3 7 . 8 4})\end{array}$ \\
\hline $\mathbf{C}$ & Zaid & & & & & \\
\hline 1. & $\begin{array}{l}\text { Sugarcane } \\
\text { (planted) }\end{array}$ & $\begin{array}{c}0.12 \\
(8.21)\end{array}$ & $\begin{array}{c}0.38 \\
(11.58)\end{array}$ & $\begin{array}{c}0.90 \\
(14.08)\end{array}$ & $\begin{array}{l}1.52 \\
(16.96)\end{array}$ & $\begin{array}{c}0.43 \\
(11.87)\end{array}$ \\
\hline 2. & Green gram & $\begin{array}{c}0.07 \\
(4.80)\end{array}$ & $\begin{array}{c}0.12 \\
(3.65)\end{array}$ & $\begin{array}{c}0.17 \\
(2.66)\end{array}$ & $\begin{array}{c}0.23 \\
(2.56)\end{array}$ & $\begin{array}{c}0.09 \\
(2.48)\end{array}$ \\
\hline 3. & Black gram & $\begin{array}{c}0.08 \\
(5.47)\end{array}$ & $\begin{array}{c}0.17 \\
(5.18)\end{array}$ & $\begin{array}{c}0.20 \\
(3.12)\end{array}$ & $\begin{array}{c}0.24 \\
(2.67)\end{array}$ & $\begin{array}{c}0.12 \\
(3.31)\end{array}$ \\
\hline \multirow[t]{3}{*}{4.} & Vegetable & $\begin{array}{c}0.12 \\
(8.21)\end{array}$ & $\begin{array}{c}0.17 \\
(5.18)\end{array}$ & $\begin{array}{c}0.25 \\
(3.91)\end{array}$ & $\begin{array}{c}0.29 \\
(3.23)\end{array}$ & $\begin{array}{c}0.16 \\
(4.41)\end{array}$ \\
\hline & Total & $\begin{array}{c}0.39 \\
(26.69)\end{array}$ & $\begin{array}{c}0.84 \\
(25.59)\end{array}$ & $\begin{array}{c}1.52 \\
(23.78)\end{array}$ & $\begin{array}{c}2.28 \\
(25.44)\end{array}$ & $\begin{array}{c}0.80 \\
(22.09)\end{array}$ \\
\hline & $\begin{array}{l}\text { Gross cropped } \\
\text { area (ha) }\end{array}$ & $\begin{array}{c}\mathbf{1 . 4 6} \\
(100.00)\end{array}$ & $\begin{array}{c}\mathbf{3 . 2 8} \\
(100.00)\end{array}$ & $\begin{array}{l}6.39 \\
(100.00)\end{array}$ & $\begin{array}{c}8.96 \\
(100.00)\end{array}$ & $\begin{array}{c}3.62 \\
(100.00)\end{array}$ \\
\hline
\end{tabular}

(Figure in parentheses indicate the percentage area under crops) 
Table.2 Cropping intensity on different size group of farms in the study area

\begin{tabular}{|c|c|c|c|c|c|}
\hline S. No. & Size of farms & $\begin{array}{c}\text { No. of } \\
\text { farmers }\end{array}$ & $\begin{array}{c}\text { Net cultivated } \\
\text { area (ha) }\end{array}$ & $\begin{array}{c}\text { Gross cropped } \\
\text { area (ha) }\end{array}$ & $\begin{array}{c}\text { Cropping } \\
\text { intensity }\end{array}$ \\
\hline 1. & Marginal farms & 50 & 0.66 & 1.46 & 221.22 \\
\hline 2. & Small farms & 20 & 1.62 & 3.28 & 202.46 \\
\hline 3. & Medium farms & 16 & 3.36 & 6.39 & 190.17 \\
\hline 4. & Large farms & 14 & 4.91 & 8.96 & 182.48 \\
\hline Total/ overall average & 100 & 1.88 & 3.62 & 192.55 \\
\hline
\end{tabular}

The cropping intensity of different size group of farms, which was found highest on marginal farms (221.22 per cent) followed by small (202.47 per cent), medium (190.17 per cent), and large farms (182.48 per cent), respectively. The overall average of cropping intensity on sample farms was worked out to 192.55 percent. Cropping intensity revealed the inverse relationship with size group of farms because marginal and small farmers best use of land by divided in to different part and better use of available resource in a particular situation.

Cropping pattern and cropping intensity is very important for agriculture. Because cropping pattern the attention of farmers with viable options to grown different type of crops on their land. Cropping intensity calculated by the cropping pattern. Different type of crop grown at different season and avoid risk to crop damages. Presently Sardhana and Shrurpur khurd block analyze changing scenario of cropping pattern.

Large cropping pattern create very high cropping intensity. Cropping Intensity of crop is a most important matter of agriculture. Changing agricultural practices produce verities of crop as well as increasing cropping intensity. Cropping intensity mainly depend on cropping pattern. Cropping intensity is most essential role of play for agriculture, agricultural practices and agricultural production. High cropping intensity area produces very high percentage of agricultural product.

\section{References}

Ghazanchaii, R. Fariabi, A. (2014) Evaluation of qualitative, quantitative and economical land suitability for major crops in Dezful region. International Journal of Soil Science; 9(3):120-132. 3.

Kumar, P. Barman, R.N. Dhaka, J.M. (1997) Rapeseed and mustard production in Rajasthan: a study of instability and factor of production. Annual of Biology (Ludhiana): 1997. 13:1, 207-211.

Saikia, T.N. (1989) "Prospects of changing cropping pattern in favor of oilseed and pulses production in Assam" Agricultural Situation in India, XLIV(4), pp. 283-285.

Sen, D., Das, P.K. (1986). Factor influcing improvements in oilseeds production by small landholders. Journal of Rural Development, 5 (1), pp. 33-60.

Pandey, U.K., Sardana, P.K., Manoche, V. (1984) "An estimate of demand for and supply of cereals grains, pulses and oilseed in Haryana" Indian Journal of Agricultural Economics, 39 (1), pp.8499.

Shukla, P.C. (1983), "Problem of growth of oilseed and mustard in UP" Agro Economic Research Centre University of Allahabad, No. 54, pp.160. 


\section{How to cite this article:}

Prince Kumar and David Chella Baskar. 2020. An Economic Study: Scenario of Cropping pattern and Cropping Intensity to Mustard cultivation of Meerut district of Western Uttar Pradesh, India. Int.J.Curr.Microbiol.App.Sci. 9(06): 2989-2993.

doi: https://doi.org/10.20546/ijcmas.2020.906.359 